\title{
WYKAZ WYBRANYCH PUBLIKACJI PROFESORA FRANCISZKA GRONOWSKIEGO
}

\author{
Profesor Franciszek Gronowski jest autorem lub współautorem ok. 200 publikacji \\ naukowych (artykułów, rozdziałów w monografiach naukowych, komunikatów) \\ oraz zbliżonej liczby materiałów publicystycznych, zamieszczonych w prasie \\ lokalnej i krajowej.
}

Harmonogram ruchu jako plan pracy eksploatacyjnej taboru w żegludze śródlądowej, „Transport" 1955, nr 4.

Konieczność oparcia pracy portów rzecznych na procesach technologicznych, „Gospodarka Wodna” 1955 , nr 6.

Kierunki pogłębienia rachunku gospodarczego żeglugi śródlądowej, Zeszyty Naukowe Politechniki Szczecińskiej, „Ekonomika”, nr 1, Poznań 1957.

Krytyczne uwagi do metod planowania przewozów w transporcie publicznym, „Gospodarka Planowa" 1957, nr 3.

Drogi wodne i transport rzeczny w Polsce, „Kwartalnik Szczecińskiego Oddziału PTE” za lata 1952-1958, Wyd. Pomorskie, Szczecin-Poznań 1959.

Podstawy działania polityki komunikacyjnej państwa w zakresie tworzenia systemu transportowego, Zaszyty Naukowe Politechniki Szczecińskiej, „Ekonomika”, nr 6, Szczecin 1960.

Stan i główne tendencje rozwoju żeglugi śródlądowej na kontynencie europejskim, „Gospodarka Wodna"1960, nr 6.

Teoretyczne problemy rachunku ekonomicznego efektywności inwestycji w transporcie, Zeszyty Naukowe Politechniki Szczecińskiej, „Ekonomika”, nr 7, Szczecin 1961.

Co-operation between inland waterways of neighbouring countries, „Polish Maritime News” 1961, nr 39.

Port morski jako pojęcie techniczne i ekonomiczne, „Technika i Gospodarka Morska” 1962, nr 7-8.

Polska jako producent statków morskich, „Przegląd Zachodniopomorski” 1963, nr 2.

O systemie komunikacyjnym, „Przegląd Komunikacyjny” 1964, nr 12.

Dwadzieścia lat polskiej gospodarki morskiej na Pomorzu Zachodnim, „Przegląd Zachodniopomorski" 1965, nr 6.

Kryteria racjonalizacji przewozów, „Przegląd Komunikacyjny” 1965, nr 3.

Bałtycka i międzynarodowa konferencja żeglugowa, „Przegląd Zachodniopomorski” 1966, nr 1.

Problematyka powiązań komunikacyjnych portu morskiego z zapleczem, „Przegląd Zachodniopomorski” 1967, nr 6. 
Czynniki kształtujące system transportowy państwa socjalistycznego, Zeszyty Naukowe Politechniki Szczecińskiej nr 96, Ekonomika nr 14, Szczecin 1967.

Żegluga morska, w: Pomorze Szczecińskie w latach 1945-1965, praca zbiorowa, Wyd. Poznańskie, Poznań 1967.

Szczecin i Świnoujście - jeden czy dwa odrębne porty morskie?, „Technika Gospodarki Morskiej” 1967, nr 6.

Port morski jako stacja stacji, „Technika i Gospodarka Morska” (TGM) 1968, nr 9.

Elementy transportu, w: Ekonomika transportu, praca zbiorowa, WKiŁ Warszawa 1968.

Problematyka morska w pracach szczecińskiego ośrodka ekonomicznego, w: Dwudziestolecie nauki polskiej na Pomorzu Szczecińskim 1946-1966, Wyd. Szczecińskie Towarzystwo Naukowe, Szczecin 1968.

Powiązania zespołu portowego Szczecin - Świnoujście ze szlakiem transportowym Odry, „Przegląd Zachodniopomorski” 1969, nr 4.

Przesłanki rozwoju kabotażu morskiego w Polsce, „Przegląd Zachodniopomorski” 1970, nr 3.

Gospodarka morska, w: Rozwój województwa szczecińskiego w 25-leciu Polski Ludowej, praca zbiorowa, PWN, Poznań 1970.

Miejsce i rola portów morskich $w$ systemie transportowym kraju, „Przegląd Zachodniopomorski” 1971, nr 2.

Poszukiwanie syntetycznych mierników wartościowych do planowania i oceny działalności przedsiębiorstw spedycji międzynarodowej, „Biuletyn Ekonomiczny” 1971, t. XII.

Prognoza rozwoju transportu morskiego, w: Prognozy rozwoju gospodarki morskiej, Materiały IM nr 789, Gdańsk-Szczecin 1973.

Węzłowe problemy przyszłościowe morsko-rzecznych portów ujścia Odry w horyzoncie 2000 roku, „Przegląd Zachodniopomorski” 1974, nr 1.

Nowe technologie przewozu w światowej żegludze morskiej, Wyd. Politechniki Szczecińskiej, Szczecin 1974 (współautor I. Chrzanowski).

„Time-chartery” w polskiej polityce żeglugowej, Prace Naukowe Politechniki Szczecińskiej, „Ekonomika", Zeszyt Specjalny, Szczecin 1976.

Morsko-rzeczny zespót portowy Szczecin-Świnoujście w perspektywie, w: Odra i Nadorze, Wyd. Ksiązka i Wiedza, Warszawa 1976.

Ośrodek dydaktyczno-naukowy transportu morskiego na Politechnice Szczecińskiej, TGM 1976, nr 5.

Kierunki usprawnienia obsługi statków liniowych w porcie szczecińskim, TGM 1976, nr 9.

Zespót portowy Szczecin-Świnoujście jako ogniwo systemu transportu morsko-rzecznego, Materiały Instytutu Morskiego nr 806, Gdańsk-Szczecin 1977.

Żegluga promowa na tle przemian w światowym transporcie morskim, „Przegląd Zachodniopomorski” 1978, nr 2.

Żegluga śródlądowa (Ekonomika, eksploatacja, organizacja), WKiŁ, Warszawa 1979 (współautor S. Główczyński).

Wpływ Odry na aktywizację zaplecza zespołu portowego Szczecin-Świnoujście, TGM 1979, nr 1.

Port $w$ Rostoku, TGM 1979, nr 3.

Udziat transportowej obsługi żeglugi śródlądowej w zespole portowym Szczecin-Świnoujście, TGM 1979, nr 10. 
Transport morski Pomorza Zachodniego w 35-lecie PRL i jego perspektywy rozwojowe, „Przegląd Zachodniopomorski" 1980, nr 2-3.

Każdemu narodowi na morskim państwie zależy, „Życie Gospodarcze” 1980, nr 28.

Przeszłość i przyszłość polskiego transportu morskiego, „Przegląd Organizacji” 1980, nr 10.

Strategia i taktyka rozwoju transportu morskiego, TGM 1980, nr 11-12.

Cele $i$ warunki działania przedsiębiorstwa amatorskiego w żegludze trampowej, Prace Naukowe Politechniki Szczecińskiej nr 199, Szczecin 1982.

Polskie porty morskie u progu nowego wieku, TGM 1985, nr 4.

Porty Szczecin-Świnoujście wczoraj, dziś i jutro, TGM 1985, nr 7-8.

Instytut Ekonomiki Transportu, „Przegląd Komunikacyjny” 1986, nr 1.

40-lecie polskiej żeglugi morskiej na Pomorzu Zachodnim, Prace Naukowe Politechniki Szczecińskiej nr 308, Instytut Ekonomiki Transportu nr 21, 1986.

Przyszłość polskiej żeglugi morskiej, TGM 1986, nr 8-9.

Polska Żegluga Bałtycka - w 10-lecie działalności, TGM 1987, nr 5.

Polska Żegluga Morska w służbie gospodarki narodowej, TGM 1987, nr 1.

Węzłowe problemy światowej żeglugi morskiej połowy lat 80., „Przegląd Zachodniopomorski” 1987, nr 1.

Wybrane refleksje ogólne i szczegółowe dotyczace gospodarki morskiej, w: II Sejmik Morski, Wydawnictwo PAX, Warszawa 1987.

Żegluga śródlądowa w życiu gospodarczym kraju, Prace Naukowe Politechniki Wrocławskiej, nr 52, Wrocław 1987 (współautor).

Prognozowanie rozwoju gałęzi transportu, część „Żegluga Morska”, „Przegląd Komunikacyjny” 1987, nr 4-5.

Problemy rozwoju transportu morskiego Polski, w: Problemy rozwoju transportu w Polsce, Wyd. US, Szczecin 1987.

Ocena sytuacji i prognozowane kierunki zmian w transporcie morskim Polski ze szczególnym uwzględnieniem Pomorza Zachodniego, w: Kierunki i determinanty społeczno - gospodarcze rozwoju Polski i regionu Pomorza Zachodniego, XXX lecie, STN, Szczecin 1987.

Uwarunkowania ekonomiczne powiązań portu $z$ miastem i regionem, w: Rola portów morskich w układzie funkcjonalnym miasta i regionu Zachodniopomorskiego, Wyd. Naukowe US, Szczecin 1988 (współautor Z. Borzycki).

Polska żegluga promowa na Bałtyku - stan i perspektywy, Zeszyty Naukowe US, nr 21, Prace Instytutu Ekonomiki Transportu nr 24, 1988.

Świat i Polska w żegludze morskiej połowy lat osiemdziesiątych, w: III Sejmik Morski, Wydawnictwo PAX, Warszawa 1988.

20 lat działalności Rady Techniczno-Ekonomicznej PŻM, TGM 1988, nr 6.

Miejsce żeglugi śródlądowej $w$ rozwiązywaniu problemów transportowych kraju i podnoszeniu efektywności ekonomicznej transportu, Odra i Nadodrze, Instytut Śląski w Opolu, 1988 (współautor).

Okołoziemskie serwisy żeglugowe - uwarunkowanie i skutki, TGM 1989, nr 8-9.

Żegluga morska Pomorza Zachodniego - jej stan i perspektywy, w: Estuarium Odry i Zatoka Pomorska w rozwoju społeczno-gospodarczym kraju, Uniwersytet Szczeciński, Szczecin 1990. 
Współczesne funkcje w przeobrażeniach strukturalnych światowych portów morskich, Zeszyty Naukowe US, nr 60, Prace Instytutu Ekonomiki Transportu nr 27, 1991.

Przyszłość żeglugi morskiej na Pomorzu Zachodnim, Zeszyty Naukowe US, nr 96, Prace Wydziału Transportu i Łączności nr 2, 1992.

Transport morski Polski na tle przeobrażeń gospodarki światowej, w: VII Sejmik Morski, Wydawnictwo PAX, Warszawa 1992.

Największy polski armator - jego przyszłość, Zeszyty Naukowe US, nr 130, Prace Wydziału Transportu i Łączności nr 5, 1994.

Polityka morska Polski?, „Budownictwo Okrętowe i Gospodarka Morska” 1994, nr 4.

Skutki transformacji ustrojowej w Polskiej Marynarce Handlowej, „Przegląd Zachodniopomorski" 1994, nr 1 .

Przemiany organizacyjno-własnościowe w PŻM - doświadczenia, perspektywy, szanse i zagrożenia, w: Przekształcenia własnościowe i strukturalne w gospodarce morskiej, IX Sejmik Morski, Katolickie Stowarzyszenie „Civitas Christiana”, Szczecin 1994.

Dziesięciolecie Sejmików Morskich, w: Państwo i samorząd terytorialny w polityce morskiej, X Jubileuszowy Sejmik Morski, Katolickie Stowarzyszenie „Civitas Christiana”, Szczecin 1995.

Czy państwo może sobie pozwolić na pełny liberalizm, rezygnując z protekcjonizmu, w: Państwo i samorząd terytorialny $w$ polityce morskiej, X Jubileuszowy Sejmik Morski, Katolickie Stowarzyszenie „Civitas Christiana”, Szczecin 1995.

Żegluga morska, w: 50 lat Polskiej gospodarki morskiej na Pomorzu Zachodnim 1945-1995, Wydawnictwo Foka, Szczecin 1995.

Skutki transformacji ustrojowej w Polskiej Marynarce Handlowej, „Przegląd Zachodniopomorski” 1995, nr 4.

Podstawowe uwarunkowania działalności przedsiębiorstw gospodarki morskiej, w: Zachodniopomorskie Forum Finansowe '95, Szczecin 1995.

Niemiecki przemysł okrętowy, konkurent i kooperant, „Budownictwo Okrętowe i Gospodarka Morska" 1995, nr 4.

Polityka morska Polski na rozdrożu, Zeszyty Naukowe WSM Szczecin, nr 50, Szczecin 1995.

50 lat żeglugi morskiej na Pomorzu Zachodnim, w: XI Sejmik Morski, Katolickie Stowarzyszenie „Civitas Christiana”, Szczecin 1996.

Szanse i zagrożenia polskich portów morskich, Zeszyty Naukowe US, nr 188, Prace Wydziału Transportu i Łączności nr 9, 1997.

Gospodarka morska Pomorza Zachodniego w dobie transformacji, „Przegląd Samorządowy” 1997, nr 5.

Gospodarka morska Pomorza Zachodniego jako pole współpracy międzyregionalnej i międzynarodowej, w: Kongres Pomorski, Szczecin 1999.

Encyklopedia Szczecina, t. 1 A-O, Szczecin 1999 (współautor).

70-letnie tradycje polskiej żeglugi liniowej, w: Nowe uwarunkowania funkcjonowania i rozwoju polskiej żeglugi liniowej i promowej, praca zbiorowa, Wyd. Fundacja na rzecz Uniwersytetu Szczecińskiego, Szczecin 2003.

From road to sea, w: Szanse i zagrożenia dla interesów polskich przewoźników liniowych i promowych wynikające z funkcjonowania na wspólnym rynku transportowym Unii Europejskiej, red. H. Salmonowicz, Wyd. Fundacja na rzecz Uniwersytetu Szczecińskiego, Szczecin 2004. 
Rys historyczny morskich przewozów pasażerskich $w$ relacjach międzykontynentalnych, $\mathrm{w}$ : Transport morski i lotniczy w obstudze ruchu pasażerskiego, red. H. Salmonowicz, Wyd. Naukowe Uniwersytetu Szczecińskiego, Szczecin 2005.

Problematyka żeglugi i transportu w tematyce Sejmików Morskich, w: Gospodarka morska w Polsce w latach 1985-2004, XX Jubileuszowy Sejmik Morski, red. A. Szwichtenberg, Katolickie Stowarzyszenie „Civitas Christiana”, Gdańsk 2005.

Sejmiki Morskie - geneza, cele, rzeczywistość, w: Europa Bałtycka. Przeszłość, teraźniejszość, nowe wyzwania, XXV Sejmik Morski, Zeszyty Naukowe US, Ekonomiczne Problemy Usług, nr 49, Szczecin 2010.

Transport $w$ teorii i praktyce - w dobie globalizacji, „Logistyka” 2012, nr 6. 